Agrovoc descriptors: aesculus; lepidoptera; geographical distribution; identification; monitoring; pest insects; infection

Agris category code: H10, L20

COBISS code 1.01

\title{
The Occurrence of some Lepidopterous species on the horse chestnut (Aesculus hippocastanum L.) at Istanbul-Belgrad Forest in Turkey
}

\author{
H. Huseyin CEBECI ${ }^{1}$, Sabiha ACER ${ }^{2}$
}

Received: February 19, 2007; accepted: June 20, 2007.

Prispelo 19. februarja 2007; sprejeto 20. junija 2007.

\begin{abstract}
The occurrence of some Lepidopterous species was determined between 2004 and 2005 on the horse chestnuts of Istanbul-Belgrad Forest in Turkey. The following eleven pests of the horse chestnut were recorded: Cameraria ohridella (Deschka \& Dimic, 1986) (Gracillariidae), Archips crataegana (Hübner, 1799), A. podana (Scopoli, 1763), A. xylosteana (Linnaeus, 1758) (Tortricidae), Crocallis elinguaria (Linnaeus, 1758), Ennomos quercaria ([Hübner], [1812]), E. quercinaria (Hufnagel, 1767), Erannis defoliaria (Clerck, 1759), Operophtera brumata (Linnaeus, 1758), Pachycnemia hippocastanaria (Hübner, 1799) (Geometridae) and Amphipyra pyramidea (Linnaeus, 1758) (Noctuidae).
\end{abstract}

Key words: Lepidoptera, horse chestnut, pests, Istanbul, Turkey.

\section{IZVLEČEK}

\section{POJAV NEKATERIH VRST LEPIDOPTER NA DIVJEM KOSTANJU (Aesculus hippocastanum L.) V GOZDU ISTANBUL-BELGRAD V TURČIJI}

V letih 2004 in 2005 je bil ugotovljen pojav vrst Lepidopter na divjem kostanju $v$ gozdu Istanbul-Belgrad $v$ Turčiji. Ugotovljenih je bilo naslednjih enajst škodljivcev: Cameraria ohridella (Deschka \& Dimic, 1986) (Gracillariidae), Archips crataegana (Hübner, 1799), A. podana (Scopoli, 1763), A. xylosteana (Linnaeus, 1758) (Tortricidae), Crocallis elinguaria (Linnaeus, 1758), Ennomos quercaria ([Hübner], [1812]), E. quercinaria (Hufnagel, 1767), Erannis defoliaria (Clerck, 1759), Operophtera brumata (Linnaeus, 1758), Pachycnemia hippocastanaria (Hübner, 1799) (Geometridae) and Amphipyra pyramidea (Linnaeus, 1758) (Noctuidae).

Ključne besede: Lepidoptera, divji kostanj, škodljivci, Carigrad, Turčija.

1 Ph.D., corresponding author, Istanbul University Faculty of Forestry, Forest Entomology and Protection Department, Sariyer, 34473, Istanbul-Turkey, Tel.: 00902122261100 ext. 25265, Fax: 009021222611 13, E-mail: hcebeci@istanbul.edu.tr

2 Biologist, Istanbul University Faculty of Forestry, Forest Entomology and Protection Department, Sariyer, 34473, Istanbul-Turkey, Tel.: 00902122261100 ext. 25269, Fax: 009021222611 13, E-mail: sacer@istanbul.edu.tr 


\section{INTRODUCTION}

The general area of Turkey is 77.056.192 ha. The forested area is 21.188 .747 ha, so $27.5 \%$ of the land in the country is covered with forests (Anonymous, 2006a). The Belgrad Forest corresponding to $0.03 \%$ of forested areas in Turkey covers an area of 5.444 ha. Elevation in the area ranges from 40 to 230 meters. The climate of Belgrad Forest according to Thornthwaite classification system is humid, mesothermal oceanic with a moderate water deficit in summer. The soils are shallow to deep, gravely, loamy clay in texture, rich in organic matter with medium to good permeability rates. Dominant vegetation includes Quercus frainetto, Q. cerris and Fagus orientalis tree species mixed with varying amounts of Acer campestre, A. trautvetteri, Alnus glutinosa, Carpinus betulus, Castanea sativa, Populus tremula, Sorbus torminalis and Ulmus campestris with a normal crown closure (Yaltirik, 1966; Kantarci, 1980; Karaoz, 1988; Ozyuvaci et. al., 2004).

The name of horse chestnut is given for its speciality of being used against heaves (Chronic Obstructive Pulmonary Disease) after completing of the horse racing. This tree species with a domed crown grows up to about height of $25 \mathrm{~m}$. The outer branches of the old trees lean out of during vegetation period because of heights of leaves. During winter season branches falling leaves turn towards up again. The leaves are opposite and palmately compound, with leaflets; each leaflet is $10-25 \mathrm{~cm}$ long, making the whole leaf up to $50 \mathrm{~cm}$ across, with a $20 \mathrm{~cm}$ petiole (Anonymous, 2006b; Anonymous, 2007). A. hippocastanum is an exotic plant species for Turkey and is widely cultivated in Belgrad Forest. A. hippocastanum is generally used for parks and gardens or afforestation of gaps because of the fast and good growing on each area such as native species. It offers an aesthetic image and protection against the noises, dusts, air pollutions and heat in urban areas of Turkey. The horse chestnut is also an ornamental plant species used in Landscape architecture planning. But, there is almost no information about its pests in Turkey. Although some insects were observed feeding on A. hippocastanum but more of this studies investigated directly Lepidopterous species that cause problems on this tree species. On the other hand, in European and Balkan countries it is especially well known the A. hippocastanum is severely damaged by some insects (Ariëns, 2004; Augustin et. al., 2004; Avtzis, 2004; Baraniak et. al., 2004; Del Bene / Gargani, 2004; Gininenko, 2004; Girardoz et. al., 2004; Johne et. al., 2006; Matošević, 2004; Matošević et. al., 2006; Milevoj, 2004; Milevoj / Pivk, 2004; Perju et. al., 2004; Subchev et. al., 2004; Tilbury et. al., 2004). In contrast, nobody investigated insect problems on this tree species in Turkey. Therefore, the aim of this study was to investigate harmful Lepidopterous species causing disease on horse chestnut adapting itself the climate conditions of Turkey.

\section{MATERIAL AND METHODS}

This study was conducted between 2004 and 2005 years in Istanbul-Belgrad Forest. The horse chestnut trees are distributed on sites (1, 2, 3, 4 and 5) in forest area (Figure 1). The horse chestnut trees were monitored for the presence of pests. Larvae on infested leaves, parts of trunks and shoots were picked up from April to October. The pests were fed regularly inside glass bottles covered organdy mesh in the laboratory. Also, Cameraria ohridella was monitored into bags hanging on tree brunches. Relative humidity in the laboratory was maintained $60-70 \%$ within $20-24^{\circ} \mathrm{C}$. The emerged adults were killed in killing jars with ethyl acetate. Each specimen was pinned using a no: 1 insect pin and the wings were mounted on 
a spreading board. After, the dried specimens were numbered and placed in insect boxes. Each Lepidopteran specimen was identified using our collections by an Olympus stereomicroscope.
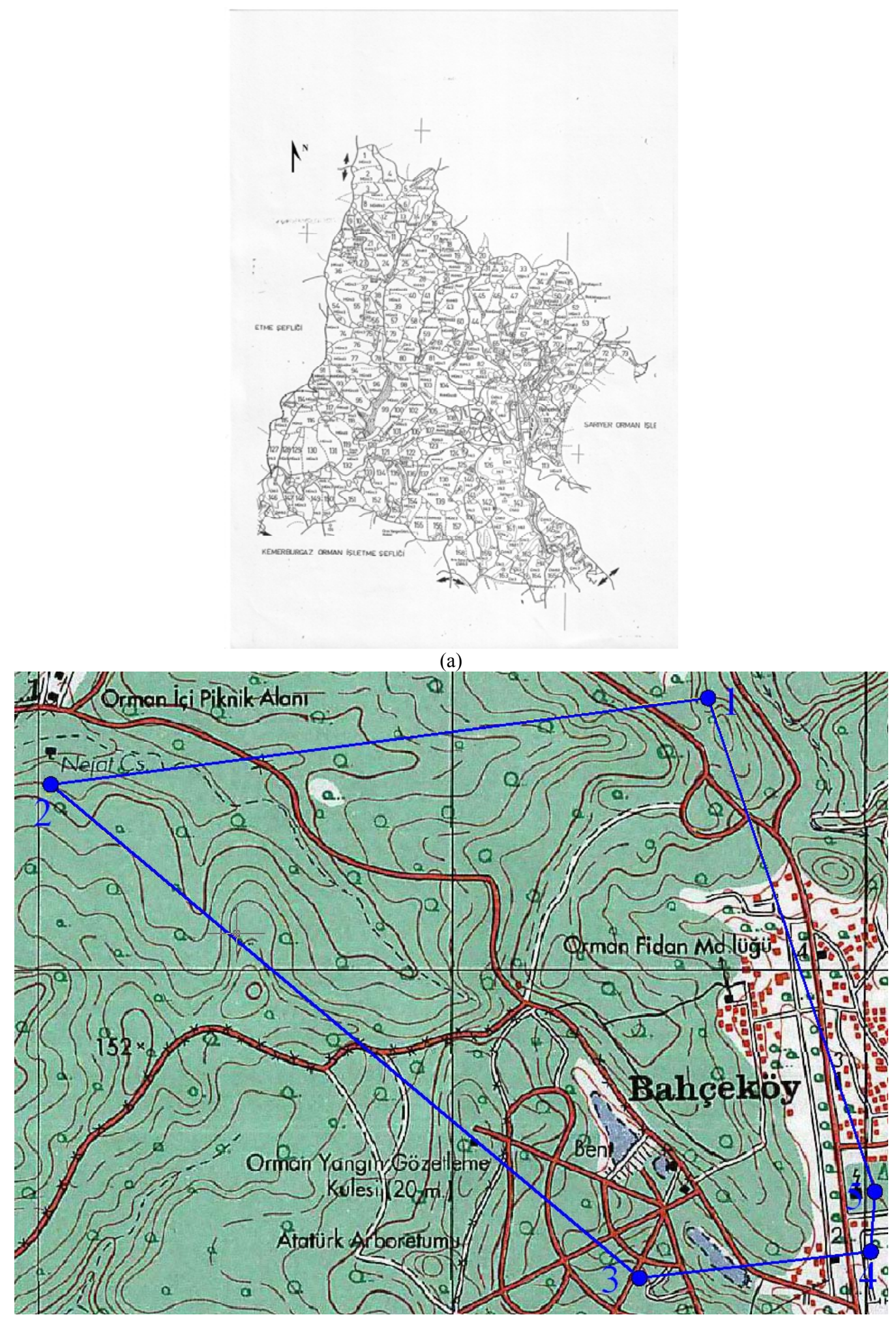

(b)

Figure 1. (a) The map of Belgrad Forest.

(b) Sites of founded chestnut trees in forest area (1, 2, 3, 4 and 5) 


\section{RESULTS}

Lepidopteran species determined belong to four families Gracillariidae, Tortricidae, Geometridae and Noctuidae, and are shown below:

Cameraria ohridella (Deschka \& Dimic, 1986) (Gracillariidae)

04.vi.2004 (larva), 06.ix.2004 (pupa), 27.ix.2004, 1 §ं; 04.vii.2004 (larva), 10.ix.2004 (pupa), 01.x.2004 1 ふో; 11.viii.2004 (larva), 15.ix.2004 (pupa), 04.x.2004, 1 ᄋ; 11.viii.2004 (larva), 12.ix.2004 (pupa), 02.x.2004, 1 o; 12.ix.2004 (larva), 17.ix.2004 (pupa), 13.x.2004, 1 क; 11.viii.2005 (larva), 04.ix.2005 (pupa), 24.ix.2005, 1 o ; 11.viii.2005 (larva), 05.ix.2005 (pupa), 30.ix.2005, 1 ぶ; 06.ix.2005 (larva), 10.ix.2005 (pupa), 03.x.2005, 1 ऽ.

The moth was more abundantly in the study field. It was founded 3-9 larvae in point of numbers on each leaf, generally 6-9 larvae on lower branches and 3-5 larvae mid branches.

Archips crataegana (Hübner, 1799) (Tortricidae)

Istanbul-Bebek, Belgrad Forest on Crataegus monogyna and Quercus robur (De Lattin, 1951; Avci, 1997; Kocak / Seven, 2001a).

04.v.2005 (larva), 13.v.2005 (pupa), 30.v.2005, 1 §..

Archips podana (Scopoli, 1763) (Tortricidae)

Adana, Bursa, Canakkale, Istanbul, Izmit, Kirklareli on Cornus mas, Corylus colurna, Fraxinus angustifolia, Malus sp., Populus sp., Quercus frainetto, Rosa sp. and Tilia argentea (Osthelder, 1935; Bodenheimer, 1941; De Lattin, 1951; Yigit / Uygun, 1982; Avci, 1997; Kocak, / Seven, 2001a; Ozbek / Calmasur, 2005).

03.v.2004 (larva), 25.v.2004 (pupa), 07.vi.2004, 1 ふో; 05.v.2004 (larva), 18.v.2004 (pupa), 05.vi.2004, 1 क; 11.v.2005 (larva), 02.vi.2005 (pupa), 09.vi.2005, 1 §ิ.

Archips xylosteana (Linnaeus, 1758) (Tortricidae)

Bartin, Bursa-Mustafakemalpasa, Istanbul-Alemdag, Belgrad Forest, Florya, Yildiz Park, Izmir-(Bornova, Torbali), Kirklareli-Kofcaz, Kocaeli on Acer campestre, Ailanthus sp., Carpinus betulus, Cercis siliquastrum, Corylus colurna, Fraxinus sp., F. ornus, Lonicera sp., Pistacia sp., Platanus sp., Populus tremula, Rubus sp., Quercus sp., Q. petraea subsp. iberica, Q. robur, Rhododendron sp., Rosa sp., Salix sp., Tilia argentea, Ulmus sp. (Bodenheimer, 1941; Acatay, 1943; Aysu, 1951; Alkan, 1962; Sekendiz, 1974; Canakcioglu, 1982; Uzun / Yalcin, 1992; Avci, 1997; Kocak / Seven, 2001a; Ozbek / Calmasur, 2005).

30.iv.2004 (larva), 18.v.2004 (pupa), 06.vi.2004 1 ふో; 5.v.2004 (larva), 17.v.2004 (pupa), 31.v.2004 1 +; 11.v.2004 (larva), 18.v.2004 (pupa), 10.vi.2004 1 \%; 10.v.2005 (larva), 17.v.2005 (pupa), 30.v.2005 1 ㅇ.

Crocallis elinguaria (Linnaeus, 1758) (Geometridae)

Usak-Akse plantation (Mol, 1977; Kocak / Seven, 2001b).

11.v.2005 (larva), 18.v.2005 (pupa), 20.vi.2005 1 §ે.

Ennomos quercaria ([Hübner], [1812]) (Geometridae)

Istanbul-Belgrad Forest, Kirklareli-Demirkoy, Aegean region on Aesculus hippocastanum, Carpinus betulus, Fagus orientalis, Quercus petraea subsp. iberica, Q. pubescens, Q. robur and Salix sp. (Mol, 1977; Kocak / Seven, 2001b).

25.iv.2004 (larva), 28.v.2004 (pupa), 07.vi.2004, 1 ふ;; 03.v.2004 (larva), 30.v.2004 (pupa), 14.vi.2004, 1 \%.

Ennomos quercinaria (Hufnagel, 1767) (Geometridae)

Bursa, Istanbul-Sariyer, Kirklareli-Demirkoy, Kirsehir on Quercus sp. (Staudinger, 1881; Kansu, 1963; Okyar / Aktac, 1999). 
05.v.2004 (larva), 30.v.2004 (pupa), 11.vi.2004, 1 q; 05.v.2004 (larva), 31.v.2004 (pupa), 10.vi.2004 1 ㅇ.

Erannis defoliaria (Clerck, 1759) (Geometridae)

Bursa-Karabelen, Edirne-Tavuk Forest, Istanbul-Belgrad Forest, Kahramanmaras, Kirklareli-Demirkoy, Samsun-Gelemen, Trabzon-Meryemana on Acer platanoides, Alnus glutinosa, Betula sp., Carpinus betulus, Castanea sativa, Corylus colurna, Fagus orientalis, Quercus robur, Rosa sp., Salix alba, Sorbus torminalis, Tilia sp. and Ulmus sp. (Osthelder, 1935; Mol, 1977; Ozay, 1997; Yuksel, 1998; Okyar / Aktac, 1999; Kocak / Seven, 2001b).

05.v.2004 (larva), 17.v.2004 (pupa), 28.xii.2004, 1 q; 05.v.2004 (larva), 18.v.2004 (pupa), 03.i.2005, 1 §ं; 05.v.2004 (larva), 18.v.2004 (pupa), 17.i.2005, 1 §; 11.v.2004 (larva), 19.v.2004 (pupa), 06.i.2005, 1 đ;; 04.v.2005 (larva), 17.v.2005 (pupa), 11.i.2006, 1 ô.

Operophtera brumata (Linnaeus, 1758) (Geometridae)

Canakkale-Koru Mountain, Edirne-Tavuk Forest, Istanbul-Belgrad Forest, KirklareliDemirkoy-Igneada, Aegean region on Acer sp., Carpinus betulus, Castanea sativa, Corylus colurna, Populus sp., Quercus sp., Q. petraea subsp. iberica, Q. robur, Rhododendron sp., Salix sp., S. alba, Ulmus sp. (Mol, 1977; Ozay, 1997; Okyar / Aktac, 1999; Kocak / Seven, 2001b).

03.v.2004 (larva), 20.v.2004 (pupa), 01.i.2005, 1 ふో; 03.v.2004 (larva), 20.v.2004 (pupa), 24.i.2005, 1 \&; 03.v.2004 (larva), 20.v.2004 (pupa), 03.i.2005, 1 §̊; 03.v.2004 (larva), 20.v.2004 (pupa), 18.i.2005, 1 đ; 04.v.2005 (larva), 17.v.2005 (pupa), 30.xii.2005, 1 क; 04.v.2005 (larva), 31.v.2005 (pupa), 14.i.2006, 1 \%; 04.v.2005 (larva), 30.v.2005 (pupa), 17.i.2006, 1 đ; 10.v.2005 (larva), 29.v.2005 (pupa); 13.i.2006, 1 §.

Pachycnemia hippocastanaria (Hübner, 1799) (Geometridae)

Amasya, Bursa, Canakkale-Ecebat (Staudinger, 1881; Okyar / Aktac, 1999; Kocak / Seven, 2001b).

30.iv.2004 (larva), 20.v.2004 (pupa), 18.i.2005, 1 §̊; 04.v.2005 (larva), 16.v.2005 (pupa), 22.i.2006, 1 ठิ.

Amphipyra pyramidea (Linnaeus, 1758) (Noctuidae)

Duzce, Istanbul-Belgrad Forest, Tekirdag-Malkara, Zonguldak-Centre and Eregli on Carpinus betulus, Fagus orientalis, Quercus sp. (De Lattin, 1951; Hacker, 1987; Hakyemez, 1994; Kocak / Seven, 2001b; Akbulut et. al., 2003).

14.v.2004 (larva), 18.v.2004 (pupa), 17.vi.2004, 1 §.

\section{DISCUSSION AND CONCLUSIONS}

Most of obtained species are polyphagous and these species prefer forest trees than ornamentals.

Cameraria ohridella was the most important dominant insect species found on horse chestnuts in this study. However, this situation does not cause vitality problems on trees at least for now. The information about this species recorded in previous studies was not encountered during this study. Cameraria ohridella was not reported in the studies carried out previously in Turkey whereas it was the most dominant species found on chestnut trees in Belgrad Forest. Although Cameraria ohridella is well 
known species in European and Balkan countries due to its damages on $A$. hippocastanum there is no information about this insect in Turkey.

Among the collected polyphagous species, Archips crataegana, A. podana, A. xylosteana, Crocallis elinguaria, Erannis defoliaria, Operophtera brumata, Amphipyra pyramidea and the monophagous species on Quercus sp., Ennomos quercinaria, were carried out on Aesculus hippocastanum in Turkey by this study. The obtained findings related to Ennomos quercaria living on A. hippocastanum in the Belgrad Forest are harmony with the recorded literature by Mol.

\section{REFERENCES}

Acatay, A. Die forstschädlichen Insekten in der umgebung von Istanbul und besonders im Belgrader Walde, ihre Bekämpfung und Wirkung auf die Waldbewirtschaftung. Y.Z.E. Calismalarindan, Sayi:142, Ankara, 1943, VIII+163 pp (In Turkish).

Akbulut, S. / Yuksel, B. / Keten, A. The Lepidoptera (Insecta) fauna of Duzce province, Turkey. Turk J. Zool., 27(4) (2003): 257-268.

Alkan, B. Mandelbaumschedlinge, ihre verbreitung und bekamphung in der Türkei. Sonderdruck aus "University of Ankara Yearbook of the Faculty of Agriculture 1962", 9 pp.

Anonymous. Turkey's forest resources. General Directorate of Forestry, (2006a) 160 pp. (In Turkish).

Anonymous. The horse chestnut. Tema Vakfi E-Bulten, Ayin Agaci. $<$ http://ebulten.tema.org.tr/2006/Mayis/AyinAgaci.htm> (2006b) [13 July 2007] (In Turkish).

Anonymous. Aesculus hippocastanum. Wikipedia, the free encyclopedia. $<$ http://en.wikipedia.org/wiki/Common_Horse-chestnut $<$ (2007) [21 june 2007].

Ariëns, M.W.P. Development of the Cameraria ohridella population in city of Rotterdam, the Netherlands. $1^{\text {st }}$ International Cameraria Symposium, IOCB Prague March 24-27, (2004).

Augustin, S. / Guichard, S. / Gilbert, M. Pattern of invasion by Cameraria ohridella in France: A comparison with Germany. $1^{\text {st }}$ International Cameraria Symposium, IOCB Prague March 24-27, (2004).

Avci, M. The Tortricidae (Lep.) fauna of Marmara Region Forests. I.U. Fakulte Dergisi, A, 47(1) (1997):111-138. (In Turkish).

Avtzis, N.D. Three-year studies on the existence of Cameraria ohridella (Lepidoptera, Gracillariidae) in Greece: (2001-2003). $1^{\text {st }}$ International Cameraria Symposium, IOCB Prague March 24-27, (2004).

Aysu, R. Cacoecia xylosteana Lin. Tomurcuk, 6(67) (1951): 8. (In Turkish).

Baraniak, E. / Walczak, U. / Tryjanowski, P. / Zduniak, P. Effect of distance between host trees and leaf litter removal on population density of Cameraria ohridella Deschka \& Dimic, 1986 (Lepidoptera, Gracillariidae)-Pest of chestnut (Aesculus sp.) trees. Pol. J. Ecol., 52-4(2004): 569-574.

Bodenheimer, F.S. Etude sur les insectes nuisibles â l'agriculture at arboriculture et les moyens de lutte. Bayur Matbaası, Ankara, (1941), 347 pp. 
CEBECI; H. H., ACER, S.: The Occurrence of some Lepidopterous species ... 101

Canakcioglu, H. The Harmful Tortricidae (Lepidoptera) species in Turkish Forests. I.U. Orman Fakulte Dergisi, A, 32(1) (1982):17-43. (In Turkish).

Del Bene, G. / Gargani, E. Biology and control of Phyllocnistis citrella and Cameraria ohridella in central Italy. $1^{\text {st }}$ International Cameraria Symposium, IOCB Prague March 24-27, (2004).

Gininenko, Y.I. Cameraria ohridella: Penetration into east Europe. $1^{\text {st }}$ International Cameraria Symposium, IOCB Prague March 24-27, (2004).

Girardoz, S. / Kenis, M. / Quicke, D. Mortality factors affecting the different developmental stages of Cameraria ohridella Deschka \& Dimić in Switzerland. $1^{\text {st }}$ International Cameraria Symposium, IOCB Prague March 24-27, (2004).

Hacker, H. Erster beitrag zur systematischa erfassung der Noctuidae der Türkei (Lepidoptera). Atalanta 17 (1987):1-26 Abb.

Hakyemez, A. The Forest Noctuidae species of Zonguldak regional administration. I.U. Orman Fakultesi Dergisi, Seri A, 44(2) (1994): 111-133.

Johne, A.B. / Weißbecker, B. / Schütz, S. Microorganisms on Aesculus hippocastanumolfactory perspective of Cameraria ohridella (Deschka \& Dimic). Angew. Ent., 15(2006): 147-151.

Kansu, A. The Prelimanry list V of Lepidoptera fauna of Turkey. Bitki Koruma Bulteni, 3(3) (1963): 208-223. (In Turkish).

Kantarci, M.D. Untersuchungen über die boden-und standortkartierung im Belgrader Wald bei Istanbul. I.U. Orman Fakultesi Yayin No. 275, (1980), XVII + 352 pp. (In Turkish)

Karaoz, M.O. Comparison of the certain edaphic and biomass characteristics of some coniferous and deciduous forest ecosystems in Belgrad Forest near Istanbul. I.U. Orman Fakultesi Dergisi, A-38(1)(1988): 157 -190. (In Turkish).

Kocak, A.O. / Seven, S. Tentative checklist of the Turkish Lepidoptera. P2, (2001a) $<$ http://www.members.tripod.com/entlep/Checklist2.htm> [16.10.2006].

Kocak, A.O. / Seven, S. Tentative checklist of the Turkish Lepidoptera. P3, (2001b) $<$ http://www.members.tripod.com/entlep/Checklist3.htm $>$ [16.10.2006].

Lattin, G.de Türkische Lepidopteren I. I.U. Fen Fak.Mec., Seri B, 15(4) (1951): 301-328.

Mataraci, T. Trees. TEMA Yayin No:39 (2002) (In Turkish).

Matošević, D. Insect pests on ornamental trees and shrubs in Zagreb. Radovi, 39(1) (2004): 37-50.

Matošević, D. / Pernek, M. / Županić, M. The effect of harmful entomofauna on plant health in the urban horticulture of Zagreb. Radovi, 41(1-2) (2006): 141-146.

Milevoj, L. The occurrence of some pests and diseases on horse chestnut, plane tree and Indian bean tree in urban areas of Slovenia. AAS, 83(2004): 297-300.

Milevoj, L. / Pivk, A. Damage to leaves of horse chestnut trees induced by the horse chestnut leafminer (Cameraria ohridella Deschka et Dimic). $1^{\text {st }}$ International Cameraria Symposium, IOCB Prague March 24-27, (2004).

Mol, T. The Geometridae species living in the forest of Marmara and Aegean Regions. I.U. Orman Fakultesi, I.U. Yayin No.2329, O.F. Yayin No.234, Istanbul, (1977), 125 pp. (In Turkish).

Okyar, Z. / Aktac, N. Faunistic and taxonomic studies on the Geometridae species of Turkish Thrace. J. of Zoology, 23(1) (1999):99-132. (In Turkish). 
Osthelder, L. Lepidopteren-fauna von Marasch in Türkish Nordsyrien. Mittel. Münch. Ent. Gesellschaft XXV, Tortricidae, Heft 2 (1935):25-55; 58.

Ozay, F.S. The Harmful insects on willows in Marmara Region in Turkey. I.U. Fen. Bil. Enst. Doktora Tezi, (1997), V+162 pp. (In Turkish).

Ozbek, H. / Calmasur, O. A Review of insects and mites associated with roses in Turkey. Acta Horticulturae 690: I. International Rose Hip Conference, 30 September 2005.

Ozyuvaci, N. / Ozhan, S. / Gokbulak, F. / Serengil, Y. / Balci, A.N. Effect of selective cutting on streamflow in an oak-beech forest ecosystem. Water Resources Management 18 (2004): 249-262.

Perju, T. / Oltean, I. / Oprean, I. / Ecobici, M. The pests of horse chestnut tree-Aesculus hippocastanum in Romania. Journal of Central European Agriculture, No. 4, 5(2004): 331-336.

Sekendiz, O.A. Investigations on animal pests of willow in Turkey. K.T.U. Orman Fakultesi, Yayin No.3, (1974), IX+194 pp. (In Turkish).

Staudinger, O. Lepidopterenfauna Kleinasien's. Horae Soc. Ent. Ross. 16 (1881):65-135.

Subchev, M. / Mircheva, A. / Hristov, B. / Tomov, R.I. Phenology of Cameraria ohridella Deschka \& Dimic (Lepidoptera: Gracillariidae) in Bulgaria. $1^{\text {st }}$ International Cameraria Symposium, IOCB Prague March 24-27, (2004).

Tilbury, C. / Straw, N.A. / Evans, H. Recent establishment of horse chestnut leaf-miner, Cameraria ohridella, in the UK. $1^{\text {st }}$ International Cameraria Symposium, IOCB Prague March 24-27, (2004).

Uzun, S. / Yalcin, E. Preliminary studies on rearing Trichogramma embryophagum Hartig, the egg parasite of Archips rosanus L. and A. xylosteana L. under controlled conditions. Zirai Mucadele Arastirma Yilligi, No.20-21 (1992): 52-53. (In Turkish).

Yaltirik, F. Studies on the floral analysis of Belgrad Forest vegetation and the main formation. Tarim Bakanligi, O.G.M. Yayinlari, Sira No: 436, Seri No: 6 (1966). (In Turkish).

Yigit, A. / Uygun, N. Studies on fauna of harmful and beneficial on apple Orchards in Adana, Icel and Kahramanmaras Provinces. Bitki Koruma Bül., 22(4) (1982):163-178. (In Turkish).

Yuksel, B. The Identification and control of damaging insect species found in the nurseries of Central and Eastern Black Sea Region. Orman Bakanligi D.K.O.A. Enst., Teknik Bulten No.7, (1998), 56 pp. (In Turkish). 